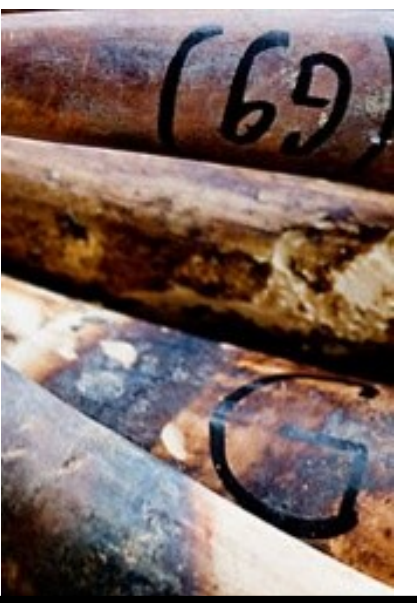

\title{
EDITORIAL: WILDLIFE CRIME POSES UNIQUE CHALLENGES TO PROTECTED AREAS
}

\author{
Nigel Dudley ${ }^{1 *}$, Sue Stolton ${ }^{2}$ and Wendy Elliott ${ }^{3}$ \\ * Corresponding author: nigel@equilibriumresearch.com \\ ${ }^{1 .}$ Industry Fellow, School of Geography, Planning and Environmental Management at the \\ University of Queensland, Equilibrium Research and IUCN-WCPA \\ ${ }^{2}$ Equilibrium Research and IUCN WCPA, Rock House, Powys, UK, sue@equilibriumresearch.com \\ ${ }^{3}$ Manager, Global Species Programme, WWF International, Avenue du Mont Blanc, Gland, 1196, \\ Switzerland, welliott@wwfint.org
}

\begin{abstract}
Wildlife crime is the fifth largest international criminal activity worldwide. Wildlife and timber poaching is becoming increasingly organised, increasingly global and more ruthless. Protected areas are suffering most acutely from this crime wave. They frequently contain the richest biodiversity and many species valued by poachers are now virtually or completely confined to protected areas. Managers, rangers and their families are intimidated, attacked and killed. Local communities suffer threats, disturbance and loss of natural resources from community reserves. Protected areas are further exposed in many countries by weak judicial processes that fail to prosecute wildlife traders even if they are caught. These developments signal the need for long-term changes in management in protected areas containing species sought by wildlife traders; more emphasis on patrolling and enforcement along with efforts to address corruption, strengthen the judiciary and improve enforcement along the rest of the trade chain. Many of these changes are unwelcome in institutions that have spent decades developing softer approaches to management. Addressing wildlife crime without losing the benefits of more transparent, consultative and participatory approaches is a challenge that requires concerted efforts by all those affected.
\end{abstract}

KEYWORDS: wildlife crime, timber poaching, enforcement, protected areas

Much of the world's protected areas network is being deliberately targeted by increasingly violent and ruthless criminal syndicates, who move their operations around the world stripping out the most valuable species for sale on the international market. Unless governments, protected area mangers, law enforcement agencies, the judicial sector and communities can improve their success at addressing these problems, protected areas will fail to deliver effective conservation for a proportion of the world's most iconic species. As protected areas are in many cases the most significant remaining habitat for these species, failure means consigning them to extinction in the wild. Addressing wildlife crime at the intensity it currently exists will require a fundamental realignment in the way in which protected areas do business, as well as a significant increase in law enforcement effort to tackle the rest of the trade chain and strategically designed efforts to reduce demand.

Crucially, the pervasive corruption which currently permeates nearly every stage of the law enforcement process in many regions must be combated for the system to function with effectiveness and political credibility (Huijbregts et al., 2013).

Over the last two decades, wildlife crime has developed into a multi-billion dollar industry; by some estimates now the fifth largest international criminal activity after narcotics, counterfeiting, and illicit trafficking of humans and oil. (Haken, 2011). As with narcotics, wildlife crime has become increasingly well organised and violent, posing a new level of threat to those responsible for managing and protecting wildlife. Problems are escalating fast, in terms of both the scale of poaching and the audacity with which poachers take high value, heavily protected species. Mass killings of hundreds of elephants in individual protected areas have now occurred in several African countries (Haken, 2011). A sudden surge in poaching effort in some areas in the last few years has caught authorities off guard. It is estimated that up to 30,00o elephants are killed in Africa each year and rhino poaching in South Africa has increased from 13 in 2007 to 668 in 2012, rolling back years of conservation effort. In many parts of the world poachers have extirpated 


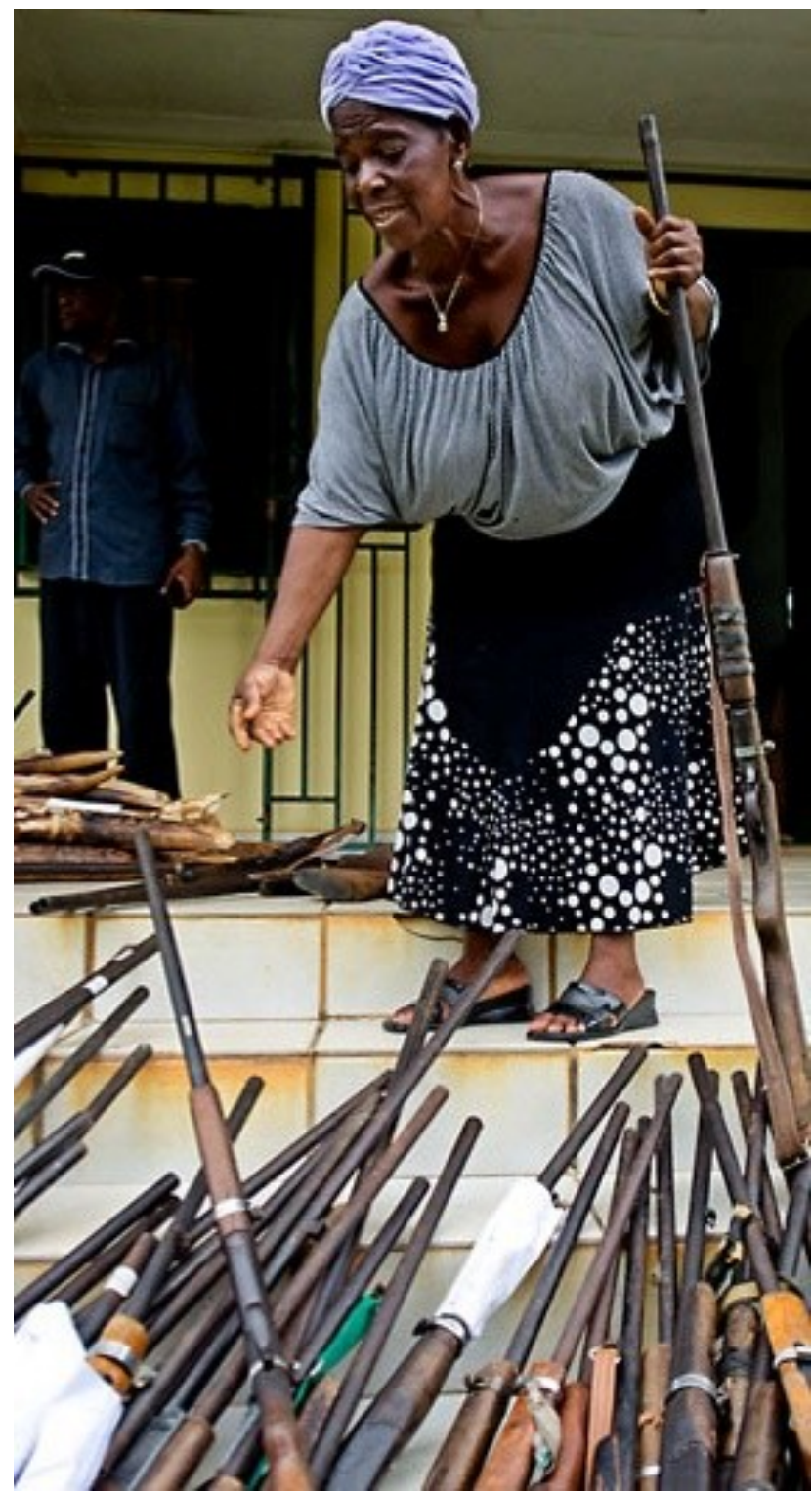

Seized poachers weapons, Gabon (C) WWF-Canon / James Morgan

species from large parts of their former range. The loss of the last population of a unique sub-species of Javan rhinoceros from Cat Tien National Park in Vietnam, was due to poaching (Brook et al., 2012). For several species whose body parts are particularly valuable to the wildlife trade, criminal activity is now a greater threat than habitat loss.

Analysts still only have an approximate idea of the scale of the problem. The legal trade in wildlife was estimated to be US\$21 billion a year in 2005 (Rosen and Smith, 2010). Estimates of the parallel illegal trade vary from US \$5-20 billion (Wyler \& Sheikh, 2008), with the high value products including tiger parts, caviar, elephant ivory, rhinoceros horn and some exotic birds and reptiles. Poaching has been a controversial issue ever since people started claiming natural resources as personal property. The poacher has often been a romantic figure in popular culture and folklore: someone relieving the rich and powerful of resources they had expropriated by force, often in turn suppressed by ruthless force of law (Thompson, 1976). There is an extent to which this attitude remains today; local communities taking game from protected areas set up on their traditional lands meet with considerable sympathy (Lewis, 1996). Similarly, both inside and outside protected areas local bushmeat hunting has been closely correlated with shortages of other foods or of money (e.g., Brashares et al., 2004, Nasi et al., 2008). Addressing these probems is challenging but is ultimately as much about negotiation and overall levels of development and wellbeing than it is to do with heavyhanded enforcement.

\section{THE PROFESSIONALIZATION OF WILDLIFE CRIME}

What is happening now is both of a different type and a different order of magnitude. Subsistence poaching is being overtaken by commercial theft of valuable wildlife products: resources for the exotic pet trade; freshwater and marine fish; and ivory and rhino horn to supply the huge markets in Asia, particularly China, Thailand and Vietnam.

Criminal syndicates involved in wildlife trafficking are increasingly well organised, with significant networks of international connections that enable them to gather and transport large quantities of illegal wildlife products across continents. Poaching gangs are better equipped, heavily armed, technologically savvy and prepared to move quickly between countries to exploit legal loopholes, areas of weak enforcement or changing demand. The amount of money involved has made the trade increasingly sophisticated, more violent and more susceptible to corruption, including of professionals within the system (such as veterinarian involvement in illegal rhino horn trade in South Africa). Illegal wildlife products are also used by rebel movements, such as the Sudan People's Liberation Army and the Janjaweed militia (WWF/Dalberg, 2012), and the Maoists in Nepal (Baral \& Heinen, 2006), to fund their activities. Governments are often either complicit (Smith \& Walpole, 2005) or unable to control the trade, which is seen as less serious than other criminal activities (e.g., Shepherd and Nijman, 2008): Corruption and abuse of power can be apparent throughout the system, for example even if poachers are apprehended they often never reach court. A recent survey of governments found mounting concern about the implications for security, sustainable development, natural resources and, due to the unregulated movement of animal parts, global health (WWF/Dalberg, 2012). 


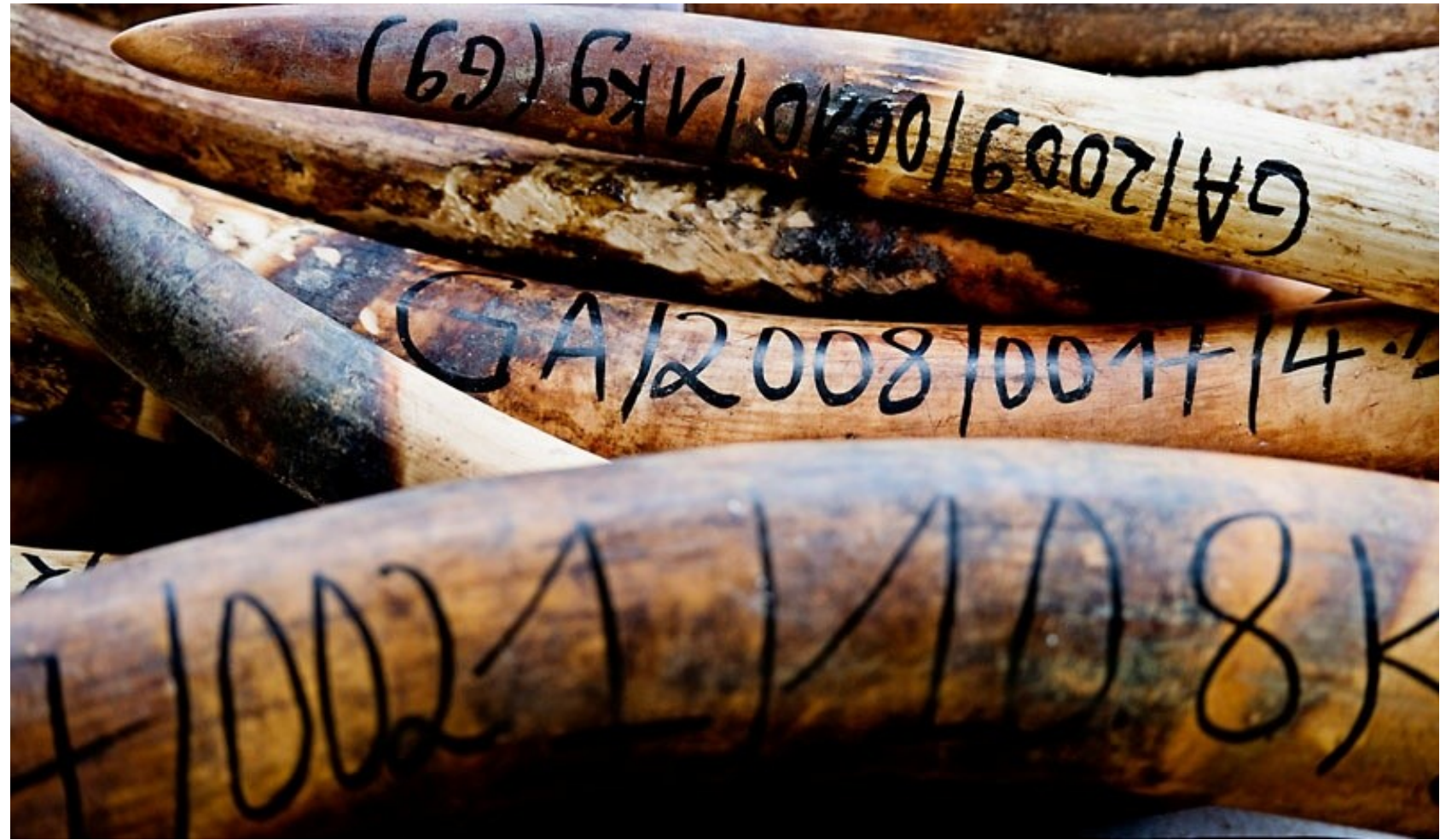

Illegally poached elephant ivory waits to be burned (C) WWF-Canon / James Morgan

Protected areas are, in many countries, the major, and sometimes the only, remaining habitat for species of conservation concern that are targeted for the illegal trade. They are therefore the focus of a large proportion of the illegal wildlife trade (e.g., Yi Ming et al., 2000); and in many countries protected areas are subject to highly criminalised poaching. Protected area agencies, primarily established and run by wildlife experts and insufficiently equipped or completely unarmed government park rangers, are now expected to respond to heavily armed criminal gangs; something akin to expecting social workers to deal with cross border drug smuggling cartels. Protected area rangers are killed every year in attempts to control poaching and there are increasing reports of intimidation against family members. Managers and rangers frequently feel unsupported by police and judiciary, and even their own hierarchies who may be complicit in the trade, and have little incentive to undertake dangerous patrolling missions.

\section{IMPLICATIONS FOR PROTECTED AREA MANAGEMENT}

For the last few decades or more, the emphasis of protected area management has increasingly been focused on softer approaches, building on negotiation, participation and consensus and consciously moving away from the rather militarised and top-down management approach of the past. Many donors have been reluctant to support law enforcement activities, which were seen as symptomatic of an old-fashioned, colonial attitude to wildlife conservation. But management by consensus only works where there is a broad agreement on values and aims, and where they system is closed to outsiders and free of violations to the agreements. The rising criminality associated with wildlife trading, mainly driven by wealthy individuals, jeopardises a consensus approach to management.It also threatens indigenous and community conserved areas as much as it does state-run reserves; many coastal communities are finding their traditional fishing reserves under threat from mobile, offshore fleets and fishing collectives are mounting armed patrols to protect their resources.

Uncomfortable though it may be, many protected area agencies responsible for species valued by the wildlife trade need to elevate enforcement much higher up their list of management priorities. There is good evidence that poaching levels are closely correlated with enforcement (e.g., Hilborne et al., 2006 reporting on Serengeti in Tanzania) and that effective enforcement can indeed help stem the tide of poaching.

For enforcement to match the current level of threat, there is a need to shift protected area management further towards performance based accountability. It is critical that all protected areas implement Adaptive Tactical Patrolling techniques, including strong Law Enforcement Monitoring systems. The creation of 


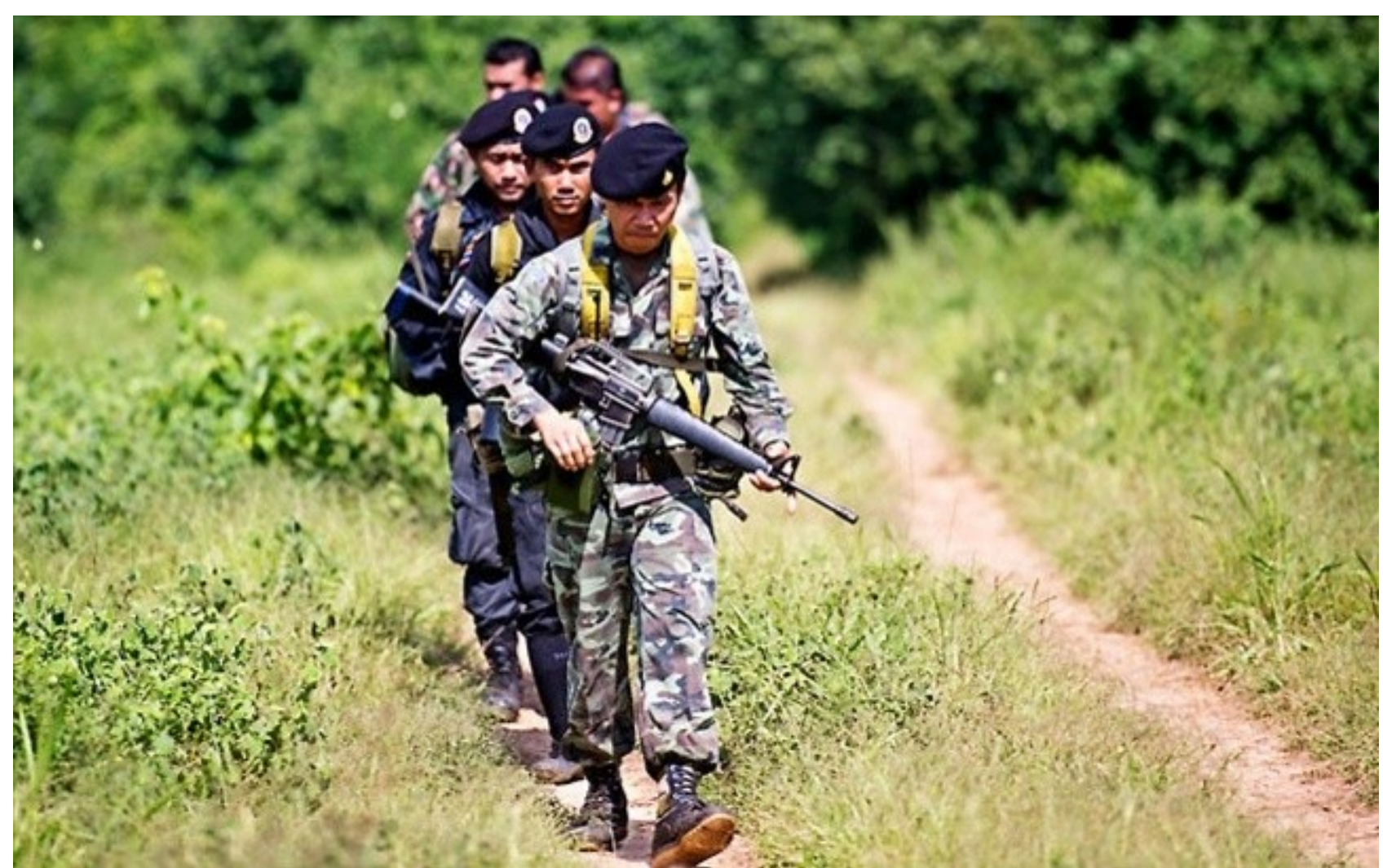

The Anti Poaching patrol team in Kui Buri National Park, set up by the Thai government in response to the recent escalation of Tiger and elephant poaching by organised wildlife crime syndicates, Thailand. Over 1,000 rangers worldwide have lost their lives protecting wildlife and natural places in the last 10 years. (C) WWF-Canon / James Morgan

protected area agencies that have legal and financial independence from central government can also help drive effectiveness. Enforcement strategies need to be location-specific, such as recognising the need for heavier patrolling activities in densely forested areas than in open plains (Jachmann, 2008) Bi- or multi-lateral government agreements can provide critical frameworks for transboundary law enforcement where protected areas cross one or more national boundaries.

Informant networks around protected area territories are also an essential tool for effective law enforcement, ensuring patrolling effort is well targeted and that poachers can be apprehended before animals are lost. All intelligence gathered from informant networks or arrested suspects should feed into national and regional intelligence systems to help articulate links to trafficking syndicates.

Agencies addressing wildlife crime also need to match the criminals in terms of technological sophistication and new tools are becoming available all the time, such as Unmanned Aerial Vehicles to facilitate patrolling, DNA profiling to track origin of traded animals (Baker et al., 2007; Wasser et al., 2007); use of satellite imagery to track ships involved in illegal fishing; and electronic coding of logs to track legal shipments. On a more fundamental level, efforts to target the criminal syndicates at the heart of the trade would be greatly facilitated by methodologies used to combat other serious crimes such as drug and arms trafficking. These include controlled deliveries, covert investigation techniques, intelligence gathering, forensics and crime scene investigation, confiscation of assets, appropriate sentencing and extradition (ICCWC, 2012).

\section{INTERNATIONAL RESPONSES}

There are signs that the global community is waking up to the scale of the threat facing wildlife and to the wider implications for human society. Formation of the International Consortium for Combating Wildlife Trade, between CITES, the Convention on International Trade on Endangered Species of Wild Flora and Fauna, INTERPOL, The World Bank, the UN Office on Drugs and Crime and the World Customs Organisation, marks a new determination to bring the full array of enforcement measures against wildlife crime (UNODC, 2012), and there is increasing engagement of non-environmental fora such as the UN Convention Against Transnational Organised Crime and the Commission on Crime Prevention and Criminal Justice. After decades of inaction, governments are starting to be held accountable for wildlife crime - the last CITES Conference of the 
Parties put several countries 'on notice' due to illegal ivory or rhino horn trade problems, with specific action required to avoid CITES compliance measures, which include sanctions. Most critically, high level politicians are increasingly acknowledging that wildlife crime is a serious crime, as outlined by the statements and commitments made by heads of state in international fora such as the Asia Pacific Economic Cooperation, the Rio+20 Outcome Document, and the UN General Assembly, although this political commitment still needs to be comprehensively translated into action.

On a more practical level, penalties for criminals convicted of wildlife trafficking are beginning to improve: in April 2013 Japan increased the maximum penalty for wildlife trafficking from one to five years and there is a growing (yet still small) number of highly significant prosecutions, such as the 40 year jail sentence given in South Africa late last year to a convicted Thai national kingpin in a rhino horn poaching racket. On-ground responses to these crimes have increased significantly in some areas - several African countries have launched elite military responses to large scale poaching threats, the latest in Cameroon involving 600 elite troops. So far the unique role of protected areas has received less attention. We need urgent steps to bring protected area agencies more centrally into strategic discussions about controlling trade; without their support - and without greater support for them in turn - these efforts are likely to be wasted.

\section{ACKNOWLEDGEMENTS}

The authors would like to thank the following people for commenting and contributing to the text: Barney Long, Manager Asian Species Conservation Programs, WWFUS; Craig Bruce, Tiger NI Protected Area and Law Enforcement Specialist, WWF; Bas Huijbregts, Head of Policy Engagement, Illegal Wildlife trade Campaign Congo Basin, WWF-Central Africa Regional Programme Office; David Greer, Coordinator African Great Apes Programme, WWF-International; Elisabeth McLellan, Manager, Species Programme, WWF-International and Jo Shaw, Rhino Co-ordinator, WWF-South Africa.

\section{REFERENCES}

Baker C.S., J.C. Cooke, S. Lavery, M.L.Dalebout, Y.U. Ma, N. Funahashi, C. Carraher and R.L. Brownell Jr. (2007). Estimating the number of whales entering trade using DNA profiling and capture-recapture analysis of market products. Molecular Ecology 16(13):2617-26., doi:10.1111/j.1365-294X.2007.03317.x.

Baral, N. and J.T. Heinen. (2006). The Maoist people's war and conservation in Nepal. Politics and the Life Sciences 24 (12): 1-11.
Brashares, J.S., P. Arcese, M.K. Sam, P.B. Coppolillo, A.R.E. Sinclair and A. Balmford. (2004). Bushmeat Hunting, Wildlife Declines, and Fish Supply in West Africa. Science 306: 1180-1183

Brook, S.M., P. van Coeverden de Groot, C. Scott, P. Boag, B. Long, R.E. Ley, G. Reischer, A.C. Williams, S.P. Mahood, Tran Minh Hien, G. Polet, N. Cox and Bach Thanh Hai. (2012). Integrated and novel survey methods for rhinoceros populations confirm the extinction of Rhinoceros sondaicus annamiticus from Vietnam. Biological Conservation 155: 59-67

Haken, J. (2011). Transnational Crime In The Developing World. Washington, DC, USA: Global Financial Integrity

Hilborn, R., P. Arcese, M. Borner, J. Hando, G. Hopcraft, M. Loibooki, S. Mduma and A.R.E. Sinclair. (2006). Effective Enforcement in a Conservation Area Science 314: 1266.

Huijbregts B., Bour P., Drori O., Elkan P., Feistner A., Froment J.M., Greer D., Gotanegre A., Douglas Hamilton I., Honing N., Ilambu O., Mathot L,. Nzooh Z., Ononino A., Pélissier C., Scholte P., Roulet P.A., De Wachter P. (2013). The ivory traffic crisis and wildlife management in Central Africa. Technical paper, March 2013

International Consortium on Combatting Wildlife Crime (ICCWC). (2012). Wildlife and Forest Crime Analytic Toolkit. Vienna, Austria: UN Office on Drugs and Crime

Jachmann, H. (2008). Illegal wildlife use and protected area management in Ghana. Biological Conservation 141: 19061918

Lewis, C. (ed.) (1996). Managing Conflicts in Protected Areas. Gland, Switzerland: IUCN

Nasi, R., D. Brown, D. Wilkie, E. Bennett, C. Tutin, G. van Tol and T. Christophersen. (2008). Conservation and use of wildlife-based resources: the bushmeat crisis. Secretariat of the Convention on Biological Diversity, Montreal, and Technical Series no. Bogor, Indonesia: 33Center for International Forestry Research (CIFOR)

Rosen, G.E. and K.F. Smith. (2010). Summarising the evidence on the internationalisation of illegal wildlife. EcoHealth 7: 24-32.

Shepherd, C.R. and V. Nijman. (2008). The trade in bear parts from Myanmar: an illustration of the ineffectiveness of enforcement of international wildlife trade regulations. Biodiversity Conservation 17: 35-42

Smith, R.J. and M.J. Walpole. 2005. Should conservationists pay more attention to corruption?. Oryx 39 (3): 251-256.

Thompson, E.P. 1976. Whigs and Hunters: The origins of the Black Act. Pantheon

UNODC (United Nations Office on Drugs and Crime). (2012). Wildlife and Forest Crime Analytic Toolkit. New York, USA: United Nations

Wasser, S.K., C. Mailand, R. Booth, B. Mutayoba, E. Kisamo, B. Clark and M. Stephens. (2007). Using DNA to track the origin of the largest ivory seizure since the 1989 trade ban. Proceedings of the National Academy of Sciences 104 (10): 4228-4233.

Wyler, L.S. and P.A. Sheikh. (2008). International illegal trade in wildlife: threats and US policy. Washington DC, USA: Congressional Research Service

Yi-Ming, L., G. Zenxiang, L. Xinhai, W. Sung and J. Niemela. (2000). Illegal wildlife trade in the Himalayan region of China. Biodiversity and Conservation 9: 901-918

WWF/Dalberg. (2012). Fighting illicit wildlife trafficking: A consultation with governments. Gland, Switzerland: WWF International 


\section{ABOUT THE AUTHORS}

Nigel Dudley is Industry Fellow, School of Geography, Planning and Environmental Management at the University of Queensland, vice chair for natural solutions for the IUCN World Commission on Protected Areas and works with Equilibrium Research in the UK. His work focuses principally on integration of protected areas into wider environmental management strategies.

Sue Stolton is lead editor of $P A R K S$ journal, a member of IUCN WCPA and the IUCN Commission on Environmental, Economic and Social Policy and works with Equilibrium Research in the UK. Her work focuses particularly on assessment of the effectiveness and wider benefits of protected areas, particularly in association with WWF, UNESCO and IUCN.

Wendy Elliott is a manager for the Global Species Programme of WWF International, and is currently one of the co-leaders of the WWF/TRAFFIC Illegal Wildlife Trade Campaign. Wendy has been with WWF for around 9 years, based from the UK, Italy and now Switzerland. Wendy's role includes supporting WWF's field programmes for flagship species, as well as international species related policy and advocacy.

\section{RESUMEN}

Los delitos contra la vida silvestre son la quinto actividad delictiva internacional más grande del mundo. La caza furtiva y la explotación maderera ilegal son actividades cada vez más organizadas, más globales y más despiadadas. Las áreas protegidas están sufriendo de forma más aguda los embates de esta ola delictiva. Con frecuencia contienen la biodiversidad más rica y muchas especies apreciadas por los cazadores furtivos están ahora práctica o totalmente confinadas a las áreas protegidas. Los administradores y los guarda parques y sus familias son intimidados, atacados y asesinados. Las comunidades locales sufren amenazas y alteraciones y la pérdida de los recursos naturales de las reservas comunitarias. Las áreas protegidas se ven más expuestas en muchos países por la debilidad de los procesos judiciales que no logran enjuiciar a los comerciantes de vida silvestre, incluso si son atrapados. Estos hechos señalan la necesidad de cambios a largo plazo en la gestión de las áreas protegidas que contienen especies buscadas por los comerciantes de vida silvestre, incluyendo más énfasis en el patrullaje y la aplicación de la ley, junto con la creación de capacidades tendientes a asegurar el apoyo eficaz de la comunidad judicial en general. Muchos de estos cambios no son bienvenidos en las instituciones que han pasado décadas desarrollando enfoques de gestión más blandos. El abordaje de los delitos contra la vida silvestre sin perder los beneficios de enfoques más transparentes, consultivos y participativos es un reto que precisa de los esfuerzos concertados de todos los afectados.

\section{RÉSUMÉ}

La criminalité contre les espèces sauvages est la cinquième activité criminelle internationale dans le monde. Le braconnage d'espèces sauvages ainsi que le trafic de bois illégal deviennent de plus en plus organisés, mondiaux et sans pitié. Les aires protégées souffrent davantage de cette vague criminelle. Elles abritent en effet souvent la plus riche diversité biologique et accueillent de nombreuses espèces valorisées par les braconniers, aujourd'hui pratiquement - voire complètement - confinées aux aires protégées. Les gestionnaires d'aires protégées, les gardes et leurs familles sont intimidés, attaqués, et même assassinés. Les communautés locales sont menacées, perturbées et dépossédées des ressources naturelles de leurs réserves communautaires. Les aires protégées sont davantage exposées dans les nombreux pays où la justice défaillante ne condamne pas les trafiquants d'espèces sauvages, même lorsque ceux-ci sont arrêtés. Il est donc essentiel de changer à long-terme la gestion des aires protégées accueillant des espèces particulièrement recherchées par les trafiquants; de mettre davantage l'accent sur les patrouilles et l'application de la loi ; et de renforcer les capacités pour fournir un soutien efficace à la communauté judiciaire dans son ensemble. Cependant, beaucoup de ces changements ne sont pas les bienvenus dans des institutions qui adoptent depuis des décennies des approches de gestion plus souples. Lutter contre la criminalité liée aux espèces sauvages sans perdre les avantages des approches transparentes, consultatives et participatives mises en place est donc un défi qui demande, pour être relevé, des efforts concertés de toutes les parties prenantes. 